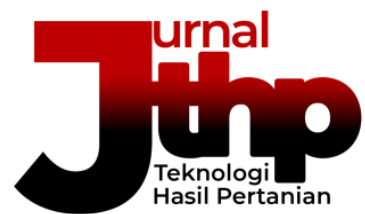

Jurnal Teknologi Hasil Pertanian. 14(2), 84-95

URL: https://jurnal.uns.ac.id/ilmupangan/article/view/53422

DOI: https://doi.org/10.20961/jthp.v14i2.53422

ISSN 1979-0309 (Online) 2614-7920 (Print)

\title{
PENGEMBANGAN TEPUNG KECAMBAH KACANG TUNGGAK (Vigna unguiculata) SEBAGAI SEREAL FUNGSIONAL KAYA SERAT PANGAN DAN BERPOTENSI ANTIOKSIDAN
}

\author{
DEVELOPMENT OF COWPEA (Vigna unguiculata) SPROUTS FLOUR AS A \\ FUNCTIONAL CEREAL HIGH IN DIETARY FIBER AND ANTIOXIDANT POTENTIAL
}

\author{
Setyaningrum Ariviani ${ }^{1,2)^{*}}$, Nurul Hidayati Sholihin ${ }^{1)}$, Galih Poetri Nastiti ${ }^{1)}$ \\ ${ }^{1)}$ Program Studi Ilmu Teknologi Pangan, Fakultas Pertanian, Universitas Sebelas Maret, Surakarta, Indonesia \\ ${ }^{2)}$ Pusat Penelitian dan Pengembangan Pangan, Gizi dan Kesehatan Masyarakat (P4GKM), \\ Universitas Sebelas Maret, Surakarta, Indonesia \\ email: setyaningrum_ariviani@staff.uns.ac.id
}

Diserahkan [18 Juli 2021]; Diterima [20 September 2021]; Dipublikasi [1 Oktober 2021]

\begin{abstract}
The average consumption of dietary fiber in Indonesian is still below the recommended daily intake. Low dietary fiber intake has an impact on the development of degenerative diseases and metabolic syndrome. One of the risk factors for the occurrence of the disease is oxidative stress. The most effective strategy to overcome oxidative stress is through dietary antioxidants intake. Cowpea is proven to be rich in bioactive compounds such as flavonoids, dietary fiber as well as antioxidants, and these compounds have been successfully increased by germination. This study aims to develop cowpea sprouts flour as a functional cereal high in dietary fiber and antioxidants. The cereal was prepared by the best formula based on two steps of sensory analysis. The first one, the sensory analysis conducted to select the formula based on the best sensory quality of the cereal made by the various proportions of cowpea flour $(\% \mathrm{~b} / \mathrm{b})(80,85,90,95,100)$. The selected formula was further used to prepare the cereal with different flavoring agents $(5 \% \mathrm{~b} / \mathrm{b})$ (ginger, cinnamon, and ginger-cinnamon) to find the best formula based on the preference level. The cereals were further analyzed to determine the sensory quality compared to the commercial cereal, the dietary fiber content which includes the total, soluble, and insoluble dietary fibers, as well as the antioxidant potential with the total phenolic content (TPC) evaluation. Formula with $80 \%(\mathrm{~b} / \mathrm{b})$ cowpea flour and $5 \%(\mathrm{~b} / \mathrm{b})$ ginger as flavoring agents produce cereal with the highest preference level and stated as the best formula. The cowpea sprouts cereal exhibited a significantly higher quality of aroma, texture, and overall than the commercial ones. The cereal also showed the highest levels of total, soluble and insoluble dietary fiber as well as the TPC. These results have significant implications on the development of functional cereal using locally legumes sprouts flour.
\end{abstract}

Keywords: cowpea sprouts flour; functional cereal; antioxidant; dietary fiber

\section{ABSTRAK}

Rerata konsumsi serat pangan di Indonesia masih di bawah asupan harian yang direkomendasikan. Asupan serat pangan yang rendah berdampak pada perkembangan penyakit degeneratif dan sindrom metabolik. Salah satu faktor risiko terjadinya penyakit tersebut adalah stres oksidatif. Strategi yang paling efektif untuk mengatasi stres oksidatif adalah melalui asupan antioksidan dari makanan. Kacang tunggak terbukti kaya senyawa bioaktif seperti flavonoid, serat pangan serta antioksidan, dan senyawa-senyawa tersebut berhasil ditingkatkan dengan perkecambahan. Penelitian ini bertujuan untuk mengembangkan tepung kecambah kacang tunggak sebagai sereal fungsional tinggi serat pangan dan antioksidan. Sereal dibuat dengan formula terbaik berdasarkan dua langkah analisis sensori. Pertama, analisis sensori yang dilakukan untuk memilih formula berdasarkan kualitas sensori terbaik dari sereal yang dibuat dengan berbagai proporsi tepung kacang tunggak (\%b/b) (80, 85, 90, 95, 100). Formula yang dipilih selanjutnya digunakan untuk menyiapkan sereal dengan flavoring agent yang berbeda $(5 \%$ b/b) (jahe, kayu manis, dan jahe-kayu manis) untuk mendapatkan formula terbaik berdasarkan tingkat kesukaan. Sereal dengan formula terbaik selanjutnya dianalisis untuk menentukan kualitas sensorinya dibandingkan dengan sereal komersial, kadar serat pangan yang meliputi serat pangan total, serat larut, dan serat tidak larut, serta potensi antioksidan dengan evaluasi kadar total senyawa fenolik (TPC). Formula dengan 
$80 \%(\mathrm{~b} / \mathrm{b})$ tepung kacang tunggak dan $5 \%(\mathrm{~b} / \mathrm{b})$ jahe sebagai flavoring agent menghasilkan sereal dengan tingkat kesukaan tertinggi dan dinyatakan sebagai formula terbaik. Sereal kecambah kacang tunggak menunjukkan kualitas aroma, tekstur, dan keseluruhan yang lebih tinggi daripada sereal komersial. Sereal kecambah kacang tunggak juga menunjukkan kadar serat pangan total, larut dan tidak larut serta TPC tertinggi. Hasil penelitian ini memiliki dampak yang signifikan terhadap pengembangan sereal fungsional dengan pemanfaatan kecambah leguminosa lokal.

Kata Kunci : tepung kecambah kacang tunggak; sereal fungsional; antioksidan; serat pangan

Saran sitasi: Ariviani, S., Sholihin, N. H., \& Nastiti, G. P. 2021. Pengembangan Tepung Kecambah Kacang Tunggak (Vigna unguiculata) sebagai Sereal Fungsional Kaya Serat Pangan dan Berpotensi Antioksida. Jurnal Teknologi Hasil Pertanian, 14(2), 84-95. https://doi.org/10.20961/jthp.v14i2.53422

\section{PENDAHULUAN}

Rata-rata konsumsi serat pangan penduduk Indonesia adalah $10,5 \mathrm{~g}$ perhari (Fitriyani, 2013). Angka ini menunjukkan bahwa penduduk Indonesia baru memenuhi sekitar sepertiga dari angka kecukupan gizi serat pangan masyarakat Indonesia menurut Permenkes RI No 28 Tahun 2019, yaitu $30-$ $37 \mathrm{~g} /$ hari untuk laki-laki dewasa dan $29-32$ $\mathrm{g} /$ hari untuk perempuan dewasa (Kemenkes RI, 2019a). Asupan serat pangan memberikan efek menguntungkan terhadap risiko berkembangnya beberapa penyakit degeneratif kronis, seperti penyakit jantung, kanker, diabetes dan obesitas (Timm dan Slavin, 2008). Menurut data Riskesdas tahun 2018, penderita penyakit degeneratif di Indonesia setiap tahunnya meningkat. Penderita diabetes mellitus, kanker, hipertensi, dan stroke berturut-turut pada tahun 2013 mencapai, 6,9\%; 1,4\%; 25,8\% dan $7 \%$ meningkat menjadi $8,5 \% ; 1,8 \% ; 34,1$ dan 10,9\% pada tahun 2018 (Kemenkes RI, 2019b). Salah satu faktor resiko terjadinya penyakit degeneratif ini adalah stress oksidatif (Liguori et al., 2018; GarcíaSánchez et al., 2020).

Stres oksidatif merupakan ketidakseimbangan antara produksi dan akumulasi ROS (reactive oxygen species) maupun RNS (reactive nitrogen species) dalam sel dan jaringan dengan kemampuan sistem biologis untuk mendegradasi dan menetralisir ROS maupun RNS tersebut (Pizzino et al., 2017; García-Sánchez et al., 2020). Ketika dijaga dalam kadar rendah atau medium, ROS bermanfaat dalam berbagai fungsi fisologis seperti sistem imun, cellular signaling pathway dan menginduksi respon mitogenik. Namun dalam jumlah yang berlebihan ROS menyebabkan kerusakan sel dan jaringan yang menginduksi beberapa penyakit degeneratif kronis seperti kanker, penyakit kardiovaskular, ginjal, pernafasan dan saraf. Asupan pangan antioksidan merupakan strategi yang efektif untuk mengatasi kondisi tersebut (Pizzino et al., 2017; García-Sánchez et al., 2020).

Antioksidan dapat bersumber dari beberapa bahan pangan seperti buah, sayur, dan legum (Carlsen et al., 2010). Legum memiliki kelebihan yaitu sebagai sumber protein karena kandungan proteinnya yang tinggi secara alami, dan tidak mudah rusak pada masa penyimpanan (Rusydi et al., 2011). Amarowicz dan Pegg (2008) melaporkan bahwa legum mengandung beragam fitokimia, karbohidrat bioaktif, dan antioksidan alami yang berperan sebagai agen antidiabetik dengan mekanisme penghambatan stress oksidatif. Kacang tunggak merupakan salah satu jenis legum multifungsional yang memiliki beberapa kelebihan dibandingkan leguminosa lain, seperti rendah lemak ( $1 \% \mathrm{db})$, kadar protein yang tinggi $(23-32 \% \mathrm{db})$, sumber mineral dan asam folat yang potensial, serta kaya akan senyawa nutrasetika seperti antioksidan dan serat pangan. Jika dibandingkan dengan kedelai, kacang tunggak memiliki produktivitas dan kadar serat pangan yang lebih tinggi serta lebih rendah lemak (Ariviani et al., 2020a). Kacang tunggak memperlihatkan berbagai manfaat kesehatan, seperti anti diabetes, anti kanker maupun anti hiperlipidemia terkait dengan kandungan senyawa fenoliknya (Ariviani et al., 2020b).

Perkecambahan merupakan cara yang efektif dalam meningkatkan komponen bioaktif maupun aktivitas antioksidan legum (Swieca et al., 2013; Swieca, 2015; Rajendra 
et al., 2019; Kristiani et al., 2019; Ariviani et al., 2020a). Perkecambahan terbukti mampu meningkatkan kadar senyawa fenolik buncis (Tarzi et al., 2012), kacang lupin (Martinez et al., 2012), kacang hijau, kedelai, kacang tunggak putih (Khang et al., 2016), selain juga meningkatkan aktivitas antioksidannya (Tarzi et al., 2012; Martinez et al., 2012). Beberapa penelitian menunjukkan bahwa perkecambahan mampu meningkatkan kadar serat pangan total, serat pangan larut maupun serat pangan tak larut leguminosa, seperti pada kacang tunggak dan kacang dolichos (Lablab purpureus L) (Benitez et al., 2013), kacang merah dan kedelai (Megat et al., 2016). Kecambah memiliki kadar air yang lebih tinggi dibanding bijinya sehingga lebih rentan terhadap kerusakan dan memiliki umur simpan yang lebih pendek. Pembuatan tepung kecambah merupakan salah satu alternatif yang bisa dilakukan untuk memperpanjang umur simpan. Teknik produksi tepung kecambah kacang tunggak terelisitasi yang mampu menghasilkan tepung dengan retensi aktivitas antioksidan dan protein terlarut serta memiliki derajat putih tertinggi adalah dengan pemanasan suhu $80^{\circ} \mathrm{C}$ selama 2 jam (Ariviani et al., 2020a).

Penelitian ini bertujuan untuk mengembangkan tepung kecambah kacang tunggak menjadi produk sereal fungsional yang kaya serat pangan dan antioksidan, sebagai salah satu alternatif penyelesaian masalah rendahnya asupan serat pangan dan meningkatnya penyakit degeneratif akibat stres oksidatif. Produk sereal dipilih karena sereal merupakan olahan pangan yang disukai berbagai kalangan. Ragam sereal semakin banyak dipasaran, tetapi sebagian hanya menonjolkan kepraktisannya (Ratna et al., 2008). Salah satu produk pangan fungsional yang berkembang pesat di Indonesia adalah sereal dari kacangkacangan dengan klaim tinggi serat (Kusumastuty et al., 2016). Penelitian pengembangan sereal yang telah dilakukan, diantaranya sereal sorgum (Hendartina 2010), sereal bekatul (Felicia, 2006), dan sereal talas (Sukasih dan Setyadjit, 2012). Pemanfaatan kacang tunggak dalam pengolahan pangan diantaranya yaitu sebagai bahan pembuatan keju nabati (Fitriana, 2015), yoghurt (Yana dan Kusnadi, 2015) dan snackbar (Rahardjo et al., 2019). Penelitian terkait sereal fungsional tepung kecambah kacang tunggak belum pernah dilakukan.

\section{METODE PENELITIAN}

\section{Bahan}

Bahan yang digunakan dalam penelitian ini adalah kacang tunggak (Vigna ungucuilata) yang diperoleh dari pasar Legi Surakarta, bahan untuk pembuatan sereal seperti gula pasir, garam, tepung pisang, tepung tapioka, vanili, mentega, ovalet, telur ayam, jahe dan kayu manis bubuk diperoleh dari toko bahan kue di Surakarta, Reagensia kimia untuk analisis meliputi FolinCiocalteau's phenol reagent, $\mathrm{Na}_{2} \mathrm{CO}_{3}$, asam galat dari Merck Millipore Co. (Darmstadt, Jerman) dan DPPH (2,2-diphenyl-1 picrylhydrazyl) diperoleh dari Sigma-Aldrich Co. (St. Louis, MO, USA).

\section{Alat}

Alat yang digunakan dalam penelitian ini dapat dibedakan menjadi empat yaitu (1) alat untuk perkecambahan berupa ember, anyaman bambu, botol spray dan gelas ukur, (2) alat untuk proses pengeringan dan penepungan meliputi cabinet dryer, blender, ayakan 60 mesh, (3) alat untuk pembuatan sereal yaitu alat pencetak, mixer, dan kompor, (4) alat untuk analisis meliputi oven (Memmert, Jerman), sentrifuse (PLC-03 Gemmy, Taiwan), vortex (VM-300 Gemmy, Taiwan), waterbath (SWB 20 Haake, Jerman), timbangan analitik (Ohaus, USA), spektrofotometer UV-Vis (Shimadzu, Jepang) serta peralatan gelas.

\section{Tahapan Penelitian}

\section{Perkecambahan kacang tunggak}

Pembuatan kecambah kacang tunggak dilakukan mengacu pada Ariviani et al. (2020a) dengan modifikasi. Kacang tunggak yang telah disortasi, selanjutnya dicuci dengan menggunakan air mengalir dengan 3 kali pembilasan. Kacang tunggak bersih selanjutnya direndam dalam akuades dengan perbandingan $(1: 3) \quad \mathrm{b} / \mathrm{v}$ selama 8 jam. 
Selanjutnya, kacang tunggak tersebut dikecambahkan selama 48 jam pada suhu ruang, dengan penyemprotan setiap 12 jam sekali menggunakan akuades. Setelah selesai proses perkecambahan, dilakukan pengupasan untuk memisahkan kulitnya, dan siap untuk tahapan penepungan.

\section{Preparasi tepung}

Proses pembuatan tepung mengacu pada Ariviani et al. (2020c). Biji kacang tunggak tanpa kulit dan kecambah kacang tunggak dikeringkan dalam cabinet dryer pada suhu $80^{\circ} \mathrm{C}$ selama 2 jam. Biji dan kecambah kacang tunggak kering dihaluskan dengan menggunakan blender berkecepatan sedang. Selanjutnya tepung yang diperoleh diayak menggunakan ayakan ukuran 60 mesh. Tepung lolos ayakan 60 mesh ini yang digunakan untuk pembuatan sereal.

\section{Formulasi sereal}

Pada tahap formulasi ini digunakan salah satu tepung, yaitu tepung kacang tunggak. Ariviani et al. (2020c) menunjukkan bahwa perkecambahan mampu meningkatkan sifat fungsional (WHC, OHC, WAC, OAC, ES) tepung leguminosa yang tentu saja akan berpengaruh pada kualitas produk hasil aplikasinya. Selain itu, perkecambahan kacang tunggak menghasilkan kenampakan, aroma, kelunakan dan cita rasa yang baik (Utomo dan Antarlina, 1998). Oleh karena itu, jika formula dengan penggunaan tepung kacang tunggak menghasilkan sereal dengan kualitas sensori yang baik, tentu saja formula tersebut akan menghasilkan sereal dengan kualitas yang baik pula jika diaplikasikan pada tepung kecambah kacang tunggak.

Tahap formulasi sereal dilakukan dalam 2 tahap. Tahap pertama untuk menentukan proporsi tepung kacang tunggak berdasarkan kualitas sensorinya. Proporsi tepung kacang tunggak $(\% \mathrm{~b} / \mathrm{b})$ yang digunakan adalah 80 , 85, 90, 95 dan 100. Analisis sensoris dilakukan dengan uji pembedaan Multiple Comparison Test (Setyaningsih et al., 2010) menggunakan 40 panelis tidak terlatih. Sebagai pembanding digunakan sereal komersial. Formula yang menghasilkan kualitas sensori terbaik, dipilih untuk formulasi tahap ke dua.
Pada formulasi tahap ke -2 , sereal dibuat dengan formula terpilih dan ditambah $5 \%$ (b/b) flavoring agent yang berbeda yaitu jahe, kayu manis, campuran jahe-kayumanis (1:1). Leguminosa secara umum memiliki flavor yang tidak diinginkan (off-flavor) seperti grassy, beany, and green flavors (Roland et al., 2017). Penambahan flavoring agent ini dimaksudkan untuk menutupi off flavor tersebut. Formula terbaik ditentukan berdasarkan hasil analisis sensori yaitu uji kesukaan (hedonik) (Setyaningsih et al., 2010) menggunakan 40 panelis tidak terlatih. Formula terbaik yang menghasilkan sereal dengan skor kesukaan tertinggi diaplikasikan dalam pembuatan sereal tepung kacang tunggak maupun tepung kecambah kacang tunggak yang selanjutnya dilakukan analisis kualitas sensoris, kadar serat pangan total, serat pangan larut dan tak larut maupun kadar fenolik total.

\section{Analisis kualitas sensoris sereal}

Kualitas sensori sereal tepung kecambah kacang tunggak maupun sereal kacang tunggak ditentukan dengan uji pembedaan metode Multiple Comparison Test (Setyaningsih et al., 2010) menggunakan 40 panelis tidak terlatih. Sereal komersial digunakan sebagai pembanding.

\section{Pembuatan sereal}

Pembuatan sereal kacang tunggak didasarkan pada pembuatan flakes Dewi et al. (2018) dengan beberapa modifikasi. Pembuatan sereal dilakukan dengan formula yang telah ditentukan. Tepung yang digunakan adalah campuran tepung kacang tunggak dan tepung pisang. Tepung dicampur dengan bahan tambahan yaitu gula pasir, garam, telur, margarin, flavouring agent terpilih dan air, sehingga membentuk adonan. Adonan tersebut kemudian dimasak dengan api kecil pada cetakan hingga matang. Setelah matang, flakes yang masih dalam bentuk lembaran kemudian diremukkan sehingga terbentuk remahanremahan kecil.

\section{Analisis kadar serat pangan total, larut dan tak larut}

Analisis kadar serat pangan dilakukan dengan metode gravimetri enzimatik (Asp et al., 1983). Proses hidrolisis enzimatik protein 
dilakukan dengan waktu inkubasi 30 menit pada suhu $60^{\circ} \mathrm{C}$ dan $\mathrm{pH} 7,5 \pm 0,1$. Proses hidrolisis enzimatik pati dilakukan dengan waktu inkubasi 30 menit pada suhu $60^{\circ} \mathrm{C}$ dan pH 4,0-4,6.

\section{Analisis potensi antioksidan}

Analisis potensi antioksidan sereal dilakukan dengan pengukuran kadar total senyawa fenolik menggunakan metode FolinCiocalteu (Singleton dan Rossi, 1999). Kadar fenolik total dinyatakan sebagai $\mu \mathrm{M}$ equivalent asam galat (GAE)/g db).

\section{Analisis data}

Data yang diperoleh dianalisis menggunakan software IBM SPSS Statistics 22 (SPSS Inc., Chicago, USA) dengan ANOVA pada taraf signifikansi $\mathrm{p}<0,05$ untuk melihat pengaruh perlakuan. Dilakukan uji lanjut DMRT pada taraf signifikansi yang sama $(\mathrm{p}<0,05)$ untuk melihat perbedaan antar pelakuan.

\section{HASIL DAN PEMBAHASAN}

\section{Formulasi Sereal}

\section{Tahap 1: Penentuan proporsi tepung kacang tunggak}

Berdasarkan Tabel 1, dapat diketahui bahwa kualitas warna, aroma, rasa tekstur maupun overall sereal dipengaruhi oleh proporsi kacang tunggak. Semakin tinggi proporsi kacang tunggak menghasilkan sereal dengan kualitas warna yang semakin rendah. Hal ini dikarenakan tepung kacang tunggak berwarna putih kecoklatan, sehingga semakin tinggi proporsi tepung kacang tunggak yang ditambahkan, maka warna sereal semakin gelap. Sereal komersial yang digunakan sebagai pembanding berwarna putih cerah, sehingga semakin tinggi proporsi kacang tunggak yang ditambahkan terlihat memiliki kualitas warna yang semakin turun. Formula $80 \%$ tepung kacang tunggak memiliki kualitas warna terbaik dibanding yang lain, namun masih lebih buruk dibanding sereal komersial. Kualitas warna ini dapat ditingkatkan dengan penambahan pewarna makanan, sehingga dapat menutupi warna gelap yang muncul akibat penggunaan tepung kacang tunggak.

Sereal dengan formula $80 \%$ dan $85 \%$ tepung kacang tunggak memperlihatkan kualitas rasa yang signifikan lebih tinggi dibanding yang lain, yaitu sedikit lebih baik dari sereal komersial. Semakin tinggi proporsi kacang tunggak menghasilkan sereal dengan kualitas rasa yang cenderung turun. Hal ini dikarenakan di dalam kacang tunggak terdapat asam glutamat bebas (DomínguezPerles et al., 2016) yang memberikan rasa umami (Kurihara, 2015), namun sebagai leguminosa, kacang tunggak juga secara alami memiliki aroma dan rasa yang tidak diinginkan (off flavor) (Roland et al., 2017). Pada proporsi kacang tunggak yang semakin tinggi, peningkatan kadar asam glutamate bebas belum memberikan peningkatan rasa umami yang mampu menutupi peningkatan off flavournya. Formula $100 \%$ kacang tunggak memberikan kualitas rasa sereal yang paling rendah dibanding yang lain.

Pada parameter aroma dapat diketahui bahwa sampel formula 80\% tepung kacang tunggak memberikan kualitas aroma sereal yang signifikan lebih tinggi dibanding yang lain, yaitu sama dengan sereal komersial. Hal ini terkait dengan off flavor yang secara alami ada di dalam leguminosa (Roland et al., 2017).

Tabel 1 Kualitas Sensori Sereal dengan Variasi Proporsi Tepung Kacang Tunggak

\begin{tabular}{|c|c|c|c|c|c|}
\hline \multirow[t]{2}{*}{ Sereal } & \multicolumn{5}{|c|}{ Skor Kualitas $^{(*)}$} \\
\hline & Warna & Rasa & Aroma & Tekstur & Overall \\
\hline $80 \%$ Kacang Tunggak & $5,78 \pm 0,66^{\mathrm{a}}$ & $4,18 \pm 0,90^{\mathrm{a}}$ & $5,03 \pm 1,12^{\mathrm{a}}$ & $4,53 \pm 0,71^{\mathrm{a}}$ & $4,88 \pm 0,85^{\mathrm{a}}$ \\
\hline 85\% Kacang Tunggak & $6,15 \pm 0,73^{b}$ & $4,43 \pm 0,84^{\mathrm{ab}}$ & $5,83 \pm 1,05^{\mathrm{b}}$ & $5,45 \pm 0,67^{\mathrm{b}}$ & $5,53 \pm 0,87^{\mathrm{b}}$ \\
\hline 90\% Kacang Tunggak & $6,35 \pm 0,74^{\mathrm{bc}}$ & $4,68 \pm 0,85^{\mathrm{bc}}$ & $5,85 \pm 0,97^{\mathrm{b}}$ & $5,43 \pm 0,63^{b}$ & $5,73 \pm 0,75^{\mathrm{b}}$ \\
\hline 95\% Kacang Tunggak & $6,45 \pm 0,63^{\mathrm{bc}}$ & $4,83 \pm 0,95^{\mathrm{bc}}$ & $5,88 \pm 0,96^{\mathrm{b}}$ & $5,38 \pm 0,66^{\mathrm{b}}$ & $5,85 \pm 0,73^{\mathrm{bc}}$ \\
\hline $\begin{array}{l}\text { 100\% Kacang } \\
\text { Tunggak }\end{array}$ & $6,55 \pm 0,87^{\mathrm{c}}$ & $4,94 \pm 1,26^{\mathrm{c}}$ & $6,00 \pm 0,90^{\mathrm{b}}$ & $5,50 \pm 0,67^{b}$ & $6,10 \pm 0,87^{\mathrm{c}}$ \\
\hline
\end{tabular}


Kualitas tekstur sereal hasilnya sama dengan kualitas aroma, yaitu sampel formula $80 \%$ tepung kacang tunggak menghasilkan sereal dengan kualitas tekstur yang signifikan lebih tinggi dibanding yang lain, yaitu sebanding dengan kualitas tekstur sereal komersial. Penggunaan tepung kacang tunggak sebesar $85 \%$ atau lebih memberikan tekstur yang agak lebih buruk dibanding sereal komersial. Hal ini mengindikasikan bahwa untuk menghasilkan sereal dengan kualitas tekstur yang sebanding dengan sereal komersial, maka maksimum penambahan tepung kacang tunggak yang dapat dilakukan adalah $80 \%$.

Berdasarkan kualitas overall dapat diketahui bahwa sampel formula $80 \%$ tepung kacang tunggak memiliki kualitas keseluruhan yang sama dengan sereal komersial, dan signifikan lebih baik dibanding formula yang lain. Sebagaimana pada kualitas rasa, Formula 100\% kacang tunggak juga memberikan kualitas keseluruhan sereal yang paling rendah dibanding yang lain. Hasil ini mengindikasikan bahwa kualitas rasa berperan penting dalam menentukan kualitas keseluruhan dari sereal. Berdasarkan kualitas warna, aroma, rasa, tekstur dan overall nya maka formula terpilih adalah formula dengan $80 \%$ tepung kacang tunggak.

\section{Tahap 2: Formula terbaik dengan penambahan flavoring agent}

Atribut sensori yang diukur pada penentuan formula terbaik dengan penambahan flavouring agent ini meliputi rasa, aroma dan overall saja. Hal ini dikarenakan penambahan flavouring agent pada penelitian ini dimaksudkan untuk menutupi off flavor yang secara alami ada pada leguminosa.

Tabel 2 memperlihatkan bahwa penambahan flavoring agent berpangaruh signifikan terhadap kesukaan panelis pada atribut rasa, aroma maupun keseluruhan. Sampel dengan formula penambahan jahe memiliki tingkat kesukaan rasa, aroma maupun keseluruhan yang signifikan lebih tinggi dibanding formula yang lain. Penambahan flavoring agent kayu manis maupun jahe-kayu manis tidak berpengaruh pada tingkat kesukaan rasa, aroma maupun overall sereal kacang tunggak, yang ditunjukkan dengan tigkat kesukaannnya tidak berbeda nyata dengan sereal tanpa penambahan flavoring agent. Formula sereal dengan penambahan flavoring agent jahe 5\% terpilih untuk digunakan sebagai formula terbaik yang akan diterapkan pada tepung kecambah kacang tunggak karena memiliki tingkat kesukaan rasa, aroma dan overall yang signifikan lebih tinggi dibanding yang lain.

\section{Kualitas Sensori}

Parameter kualitas warna tidak ditentukan pada penentuan kualitas sensori sereal kecambah kacang tunggak. Hal ini mengingat kualitas warna sereal bisa dimanipulasi dengan penambahan pewarna makanan ataupun food ingredient lain seperti bubuk coklat misalnya.

Tabel 2 Tingkat Kesukaan Sereal Kacang Tunggak dengan Variasi Flavoring Agent

\begin{tabular}{lccc}
\hline \multirow{2}{*}{ Sereal } & \multicolumn{3}{c}{ Skor Kesukaan $^{(*)}$} \\
\cline { 2 - 4 } & Rasa & Aroma & Overall \\
\hline Tanpa flavoring agent & $5,05 \pm 0,87^{\mathrm{a}}$ & $4,78 \pm 0,86^{\mathrm{a}}$ & $4,85 \pm 0,77^{\mathrm{a}}$ \\
Jahe & $5,83 \pm 0,84^{\mathrm{b}}$ & $5,68 \pm 0,88^{\mathrm{b}}$ & $5,55 \pm 0,55^{\mathrm{b}}$ \\
Kayu Manis & $5,00 \pm 0,98^{\mathrm{a}}$ & $4,93 \pm 0,94^{\mathrm{a}}$ & $5,00 \pm 0,84^{\mathrm{a}}$ \\
Jahe - Kayu Manis & $5,05 \pm 0,98^{\mathrm{a}}$ & $4,90 \pm 0,90^{\mathrm{a}}$ & $5,05 \pm 0,78^{\mathrm{a}}$ \\
\hline
\end{tabular}

Keterangan: ${ }^{(*)}$ skor 4: netral, 5: agak suka, 6: suka. Notasi huruf yang berbeda dari kolom yang sama menunjukkan terdapat perbedaan yang nyata $(\mathrm{p}<0,05)$ 
Tabel 3 Kualitas Sensori Sereal Komersial, Sereal Kacang Tunggak dan Sereal Kecambah Kacang Tunggak

\begin{tabular}{lcccc}
\hline \multirow{2}{*}{ Sereal } & \multicolumn{4}{c}{ Skor Kualitas ${ }^{(*)}$} \\
\cline { 2 - 5 } & Rasa & Aroma & Tekstur & Overall \\
\hline Komersial & $5,00 \pm 0,98^{\mathrm{a}}$ & $5,27 \pm 0,69^{\mathrm{b}}$ & $5,40 \pm 0,62^{\mathrm{b}}$ & $5,20 \pm 0,61^{\mathrm{b}}$ \\
Kacang Tunggak & $5,53 \pm 0,57^{\mathrm{b}}$ & $5,03 \pm 0,96^{\mathrm{b}}$ & $4,80 \pm 0,88^{\mathrm{a}}$ & $5,17 \pm 0,74^{\mathrm{b}}$ \\
Kecambah Kacang Tunggak & $4,97 \pm 0,89^{\mathrm{a}}$ & $4,50 \pm 0,82^{\mathrm{a}}$ & $4,53 \pm 0,73^{\mathrm{a}}$ & $4,77 \pm 0,70^{\mathrm{a}}$ \\
\hline
\end{tabular}

Keterangan: (*) Skor 4: sedikit lebih baik dari R, 5: sama dengan R, 6: sedikit lebih buruk dari R. R merupakan sereal komersil. Notasi huruf yang berbeda dari kolom yang sama menunjukkan terdapat perbedaan yang nyata $(\mathrm{p}<0,05)$

Tabel 3 memperlihatkan bahwa kualitas rasa sereal tepung kecambah kacang tunggak sama dengan sereal komersial dan signifikan lebih tinggi dibanding sereal tepung kacang tunggak. Kualitas aroma dan overall sereal kecambah kacang tunggak signifikan lebih tinggi dibanding sereal kacang tunggak maupun sereal komersial. Hasil ini mengindikasikan bahwa dengan perkecambahan mampu meningkatkan kualitas rasa, aroma maupun overall dari tepung kacang tunggak. Utomo dan Antarlina (1998) menyatakan bahwa perkecambahan kacang tunggak menghasilkan kenampakan, aroma, kelunakan dan cita rasa yang baik. Makanan pendamping ASI yang dibuat dengan tepung kecambah kacang tunggak memiliki tingkat penerimaan keseluruhan yang lebih tinggi dibanding yeng dibuat dari tepung kacang tunggak tanpa perkecambahan (Jirapa et al., 2001). Kualitas tekstur sereal kecambah kacang tunggak tidak berbeda nyata dengan sereal kacang tunggak tanpa perkecambahan. Hasil ini sejalan dengan hasil penelitian Uwaegbute et al. (2000) yang menunjukkan bahwa tidak terdapat perbedaan nyata antara tekstur moin-moin yang dibuat dengan tepung kecambah kacang tunggak dan tepung kacang tunggak tanpa perkecambahan.

\section{Serat Pangan Total, Larut dan Tak Larut}

Asupan serat pangan telah banyak dilaporkan memberikan berbagai manfaat kesehatan seperti menurunkan resiko penyakit jantung coroner, diabetes, stroke, hipertensi, gangguan pencernaan dan obesitas (Anderson et al. 2009). Menurut Barber et al. (2020) manfaat kesehatan dari serat pangan meliputi efek metabolik yaitu peningkatan sensitivitas insulin (terutama serat tidak larut), penurunan risiko diabetes tipe 2 (terutama serat tak larut dari serealia dan bijibijian), perbaikan status glikemik dan profil lipid (terutama serat larut), penurunan berat badan dan adipose abdominal; efek mikroflora usus yaitu viabilitas dan keragaman mikroflora usus serta hasil metabolitnya (termasuk asam lemak rantai pendek); efek kardivaskuler yaitu menurunkan risiko peradangan kronis, kardivaskuler dan kematian; efek depresi yaitu mengurangi peradangan kronis dan mempengaruhi mirobiota usus; efek gastrointestinal localised yaitu integritas dan kesehatan kolon, motilitas kolon, dan karsinoma kolektral. Peningkatan asupan serat pangan akan meningkatkan serum lipid, menurunkan tekanan darah, meningkatkan kontrol glukosa darah pada penderita diabetes, mencegah konstipasi, menurunkan berat badan serta meningkatkan sistem kekebalan tubuh (Anderson et al. 2009).

Data di Tabel 4 menunjukkan bahwa sereal yang dibuat dari tepung kecambah kacang tunggak memiliki kadar serat pangan total yang signifikan lebih tinggi dibanding yang dibuat dari tepung tanpa perkecambahan. Sereal kecambah kacang tunggak memiliki kadar serat pangan total $7,71 \%$ lebih tinggi dibanding sereal kacang tunggak tanpa perkecambahan. Setelah dikecambahkan, serat pangan total dari legum seperti lentil, millet, kacang merah, kedelai, kacang tunggak dan kacang dolichos (Lablab purpureus L), mengalami peningkatan (Benitez et al., 2013; Megat et al., 2016; Dueñas et al., 2016; Sharma et al., 2016). Serat pangan total pada sereal kecambah kacang tunggak maupun sereal kacang tunggak lebih tinggi dibanding sereal komersial. 
Tabel 4 Kadar Serat Pangan Total, Larut dan Tak Larut

\begin{tabular}{lccc}
\hline \multicolumn{1}{c}{ Sereal } & $\begin{array}{c}\text { Serat Pangan } \\
\text { Total }(\% \mathrm{db})\end{array}$ & $\begin{array}{c}\text { Serat Pangan } \\
\text { Larut }(\% \mathrm{db})\end{array}$ & $\begin{array}{c}\text { Serat Pangan Tak } \\
\text { Larut }(\% \mathrm{db})\end{array}$ \\
\hline Kacang Tunggak & $9,20 \pm 0,02^{\mathrm{a}}$ & $2,31 \pm 0,09^{\mathrm{a}}$ & $6,13 \pm 0,11^{\mathrm{a}}$ \\
Kecambah Kacang Tunggak $^{\text {Komersial }}$ & $9,91 \pm 0,10^{\mathrm{b}}$ & $3,37 \pm 0,07^{\mathrm{b}}$ & $6,89 \pm 0,02^{\mathrm{b}}$ \\
Komb $^{\mathrm{b}}$ & 8,734 & 2,911 & 5,823 \\
\hline
\end{tabular}

Keterangan: Notasi huruf yang berbeda dari kolom yang sama menunjukkan berbeda nyata $(\mathrm{p}<0,05) .{ }^{*}$ Dilihat dari informasi nilai gizi pada kemasan.

Kadar serat pangan larut sereal tepung kecambah kacang tunggak $45,88 \%$ lebih tinggi daripada sereal tepung kacang tunggak, yaitu mencapai $3,37 \% \mathrm{db}$ pada sereal kecambah dan $2,31 \%$ db pada sereal tepung kacang tunggak. Hal ini dikarenakan dengan perkecambahan mampu meningkatkan kadar serat pangan larut tepung leguminosa. Anita (2009) melaporkan bahwa perkecambahan mampu meningkatkan kadar serat pangan larut pada tepung kecambah kacang komak sebesar 4,86\% yaitu dari $15,85 \%$ menjadi $16,62 \%$ setelah dikecambahkan. Seral kecambah kacang tunggak menunjukkan kadar serat pangan larut yang lebih tinggi dibanding sereal komersial.

Sereal kecambah kacang tunggak memiliki kadar serat pangan tak larut yang signifikan lebih tinggi dibanding sereal kacang tunggak. Benitez et al. (2013) melaporkan bahwa kadar serat pangan tak larut kacang tunggak meningkat akibat perkecambahan. Jika dibandingkan dengan sereal komersil, baik sereal kecambah maupun kacang tunggak menunjukan kadar serat pangan tak larut yang lebih tinggi.

Komposisi serat pangan pada seral kecambah kacang tunggak maupun sereal kacang tunggak sama dengan sereal komersial yaitu memiliki kadar serat pangan tak larut yang lebih dominan dibanding serat pangan larut.

Menurut Perka BPOM No 13 Tahun 2016, klaim pangan tinggi/ kaya serat jika minimum kadar serat pangannya adalah $6 \%$ (BPOM, 2016). Sereal kecambah kacang tunggak memiliki kadar serat pangan total $9,91 \% \mathrm{db}$ atau $9,23 \% \mathrm{wb}$, sehingga berpotensi dikembangkan sebagai sereal fungsional tinggi serat pangan. Asupan serat pangan yang cukup untuk pria adalah sebesar 38 g/hari dan untuk wanita sebesar $28 \mathrm{~g} /$ hari (Dahl dan Maria, 2015). Dengan kadar serat

pangan $9,23 \% \mathrm{wb}$, sereal kecambah kacang tunggak dapat memenuhi $24,29 \%$ kebutuhan harian pria dan $32,97 \%$ kebutuhan harian wanita. Kekurangan asupan serat pangan dapat menyebabkan sejumlah penyakit seperti sembelit, hiatus hernia, radang usus buntu, diabetes, obesitas, penyakit jantung coroner dan batu empedu (Li dan Komarek, 2017).

\section{Potensi Antioksidan Sereal Kecambah Kacang Tunggak}

Potensi antioksidan sereal kecambah kacang tunggak ditentukan dengan pengukuran kadar total senyawa fenoliknya. Hasil penelitian Ariviani et al. (2020b) menunjukkan bahwa aktivitas antioksidan kecambah kacang tunggak yang meliputi RSA (radical scavenging activity) ataupun daya reduksinya (reducing power) memiliki korelasi yang tinggi dengan kadar total senyawa fenoliknya.

Beberapa penelitian telah melaporkan bahwa kacang tunggak mengandung senyawa antioksidan berupa total senyawa fenolik sebesar 38,22 mg GAE/100 g db sampel (Marsono et al., 2005), dan 35,06 $\mathrm{mg} / 100$ gr db (Ariviani et al, 2010). Berdasarkan penelitian Cai et al. (2003), tepung kacang tunggak memiliki kadar fenolik yang bervariasi dari 34,6 hingga $376,6 \mathrm{mg} / 100 \mathrm{~g}$ tepung.

Tabel 5 Kadar Total Senyawa Fenolik Sereal Kecambah Kacang Tunggak

\begin{tabular}{lc}
\hline \multicolumn{1}{c}{ Sampel Sereal } & $\begin{array}{c}\text { Kadar Total } \\
\text { Senyawa Fenolik } \\
(\mu \mathrm{M} \text { GAE/g db })\end{array}$ \\
\hline Kacang Tunggak & $4,02 \pm 0,20^{\mathrm{b}}$ \\
Kecambah Kacang & $4,61 \pm 0,00^{\mathrm{c}}$ \\
Tunggak & \\
Sereal Komersil $^{*}$ & $1,20 \pm 0,17^{\mathrm{a}}$ \\
\hline
\end{tabular}

Keterangan: Notasi huruf yang berbeda menunjukkan terdapat perbedaan yang nyata $(\mathrm{p}<0,05)$ 
Kadar total senyawa fenolik sereal kecambah kacang tunggak signifikan lebih tinggi daripada sereal kacang tunggak (Tabel 5). Perkecambahan dapat meningkatkan senyawa fenolik pada kacang tunggak putih (Khang et al., 2016) maupun kacang tunggak (Teixeira-Guedes et al., 2019). Menurut Tang et al. (2014), proses perkecambahan mengaktifkan enzim-enzim biosintesis, sehingga metabolit sekunder akan terakumulasi. Jika dibandingkan dengan sereal komersial, sereal kecambah kacang tunggak memiliki kadar total senyawa fenolik 3,8 kali lebih tinggi. Hasil ini mengindikasikan bahwa sereal kacambah kacang tunggak berpotensi sebagai sereal fungsional berpotensi antioksidan ditinjau dari kadar total senyawa fenoliknya. Ariviani et al. (2020b) melaporkan bahwa kacang tunggak berpotensi sebagai sumber antioksidan karena komponen fenolik dan flavonoidnya. Dan manfaat kesehatan dari konsumsi kacang tunggak, seperti anti diabetes, anti kanker maupun anti hiperlipidemia merupakan kontribusi dari senyawa fenoliknya.

\section{KESIMPULAN}

Formula yang menghasilkan sereal kacang tunggak dengan kualitas sensoris dan tingkat kesukaan tertinggi adalah formula dengan proporsi $80 \%(\mathrm{~b} / \mathrm{b})$ kacang tunggak dan penambahan $5 \%(\mathrm{~b} / \mathrm{b})$ bubuk jahe sebagai flavoring agent. Sereal fungsional kecambah kacang tunggak terbukti sebagai produk sereal tinggi serat dengan kadar serat pangan total, larut, dan tak larut yang signifikan lebih tinggi dibanding sereal komersial. Sereal ini juga berpotensi sebagai sumber asupan antioksidan yang ditunjukkan dengan kadar total senyawa fenoliknya yang mencapai 3,8 kali sereal komersial. Sereal kecambah kacang tunggak ini berpotensi untuk dikembangkan sebagai produk sereal fungsional komersial karena menunjukkan kualitas sensori yang tidak kalah dibanding sereal komersial yang telah ada di pasaran.

\section{DAFTAR PUSTAKA}

Amarowicz, R., dan Ronald B. Pegg. (2008). Legumes as a Source of Natural Antioxidants. Eur. J. Lipid Sci. Technol 110 (10): 865-878.

Anderson, J. W., Baird, P., Davis R. H., Ferreri, S., Knudtson, M., Koraym, A., Waters, V., dan Williams, C. L. (2009). Health benefits of Dietary Fiber. Nutrition Reviews 67(4): 188-205.

Anita, S. (2009). Studi Sifat Fisiko-Kimia, Sifat Fungsional Karbohidrat, dan Aktivitas Antioksidan Tepung Kecambah Kacang Komak (Lablab purpureus (L.) Sweet). Skripsi. Institut Pertanian Bogor.

Ariviani, S., Handajani, S., Affandi, D.R., Listyaningsih, E. (2010). Pengembangan Kacang Tunggak (Vigna unguiculata) dan Kacang Gude (Cajanus cajan) Sebagai Minuman Fungsional: Efek Hipoglikemik dan Status Antioksidan. Hibah Kompetitif Penelitian Strategis Nasional.

Ariviani, S., Mudalifah, I., Ishartani, D., dan Fauza, G. (2020a). Investigation on Antioxidant Activity, Protein, and Whiteness Degree of Elicited Cowpea Sprouts Flour Prepared with Various Drying Technique. AIP Conference Proceedings 2219, $070003 \quad$ (2020); https://doi.org/10.1063/5.0003640

Ariviani, S., Rajendra, F.M., Ishartani, D., dan Fauza, G. (2020b). Antioxidant Capacity and Germination Power of $\mathrm{NaCl}$-elicited cowpea (Vigna ungucuilata) Sprouts with Various $\mathrm{NaCl}$ Concentrations and Elicitation Durations. IOP Conference Series: Earth and Environmental Science $518 \quad$ (2020) 012020; https://doi:10.1088/1755-1315/518/012020

Ariviani, S., Lainuna, N., dan Fauza, G. (2020c). The Potential of $\mathrm{NaCl}$ Elicitation on Improving Antioxidant Capacity and Functional Properties of Sprouted Pigeon Pea (Cajanus cajan) Flour. AIP Conference Proceedings 2219, 070005 (2020a); https://doi.org/10.1063/5.0003642

Asp, C. G., Johansson, H., dan Siljestrom. (1983). Rapid Enzymatic Assay of Insoluble and Soluble Dietary Fiber. Journal Agriculture Food Chemistry 31: 476-482.

Badan Pengawas Obat dan Makanan Republik Indonesia (BPOM RI). (2016). Peraturan 
Kepala BPOM Nomor 13. Tahun 2016 Tentang Pengawasan Klaim pada Label dan Iklan Pangan Olahan. BPOM RI.

Benitez, V., Cantera, S., Aguilera, Y., Molla, E., Esteban, R. M., Diaz, M. F., dan MartinCabrejas, M.A. (2013). Impact of Germination on Starch, Dietary Fiber and Physicochemical Properties in NonConventional Legumes. Journal Food Research International 50: 64-69.

Barber, T. M., Kabisch, S., Pfeiffer, A. F. H., dan Weickert, M. O. (2020). The Health Benefits of Dietary Fibre. Nutrients 12: 1 17.

Cai R., Hettiarachy, N. S., dan Jalaluddin, M. (2003). High-Performance Liquid Chromatography Determination of Phenolic Constituents In 17 Varieties of Cowpeas. Journal of Agricultural and Food Chemistry, 51: 1623-1627.

Carlsen, M. H., Halvorsen, B., dan Holte, K. (2010). The Total Antioxidant Content of More than 3100 Foods, Beverages, Spices, Herbs and Supplements Use Worldwide. Nutrition Journal 9 (3): 1-11.

Dahl, J., dan Maria, L. (2015). Position of The Academy of Nutrition and Dietics: Health Implications of Dietary Fiber. Journal of The Academy of Nutrition and Dietics 15 (11): 1861-1870.

Dewi, I. G. A. S. P., Ekawati, I. G. A., dan Pratiwi I. D. P. K. 2018. Pengaruh Lama Perkecambahan Millet Terhadap Karakteristik Flakes. Jurnal Ilmu dan Teknologi Pangan 7 (4): 178-183.

Domínguez-Perles, R., Machado, N., Abraao, A. S., Carnide, V., Ferreiea, L., Rodrigues, M., Rosa, E. A. D. S., dan Barros, A. I. R. N. A. (2016). Chemometric Analysis on Free Amino Acids and Proximate Compositional Data for Selecting Cowpea (Vigna ungucuilata L.) Diversity. Journal of Food Composition and Analysis 53: 62-76.

Dueñas, M., Sarmento, T., Aguilera, Y., Benitez, V., Molla, E, Esteban, R.M., dan MartínCabrejas, M.A. (2016). Impact of Cooking and Germination on Phenolic Composition and Dietary Fibre Fractions in Dark Beans (Phaseolus vulgaris L.) and Lentils (Lens culinaris L.). LWT - Food Science and Technology 66: 72-78.

Felicia, A. (2006). Pengembangan Produk Sereal Sarapan Siap Santap Berbasis Shorgum.
Skripsi. Fakultas Teknologi Pertanian, Institut Pertanian Bogor.

Fitriana, Z. W. (2015). Pemanfaatan Kacang Tunggak (Vigna Unguiculata L. Walp) Sebagai Bahan Pembuatan Keju Nabati Berkalsium Tinggi. Skripsi. Fakultas Ilmu Tarbiyah dan Keguruan Universitas Islam Negeri Walisongo Semarang.

Fitriyani. (2013). Konsumsi Pangan dan Serat Makanan, Serta Status Gizi dan Status Kesehatan Wanita Hamil di Kota Bogor. Skripsi. Fakultas Ekologi Manusia Institut Pertanian Bogor.

García-Sánchez, A., Miranda-Diaz, A. G., dan Cardona-Munoz, E. G. (2020). The Role of Oxidative Stress in Physiopathology and Pharmacological Treatment with Pro- and Antioxidant Properties in Chronic Diseases. Revies Article: Oxidative Medicine and Cellular Longevity 2020: 1-16.

Hendartina, T. N. (2010). Formulasi Sereal Susu Berbahan Baku Sorghum Sebagai Pangan Sarapan. Skripsi. Fakultas Teknologi Pertanian, Institut Pertanian Bogor.

Jirapa, P., Normah, H., Zamaliah, M. M., Asmah, R., dan Mohamad, K. (2001). Nutritional Quality of Germinated Cowpea Flour (Vigna ungucuilata) and Its Application in Home Prepared Powdered Weaning Foods. Plants Foods for Human Nutrition 56: 203216.

Kementrian Kesehatan Republik Indonesia (Kemenkes RI) (2019a). Peraturan Menteri Kesehatan RI Nomor 28 Yahun 2019 Tentang Angka Kecukupan Gizi yang Dianjurkan untuk Masyarakat Indonesia. Kemenkes RI.

Kementrian Kesehatan Repiblik Indonesua (Kemenkes RI. (2019b). Laporan Nasional Riskesdas 2018. Badan Penelitian dan Pengembangan Kesehatan Kementerian RI

Khang, D. T., Dung, T. N., Elzaawely, A. A., dan Xuan, T. D. (2016). Phenolic Profiles and Antioxidant Activity of Germinated Legumes. Article Foods MDPI 5 (27): 1 10.

Kristiani, L. S., Rajendra, F. M., dan Ariviani, S. (2019). Antioxidant Capacity of Pigeon Pea (Cajanus cajan L.) Sprouts Elicited using $\mathrm{NaCl}$ with Various Elicitation Time. IOP Conference Series: Materials Science and Engineering, 633 (1): 1-5. 
Kurihara, Kenzo. (2015). Umami the Fifth Basic Taste: History of Studies on Receptor Mechanisms and Role as a Food Flavor. Review Article BioMed Research International 2015; https://dx.doi.ord/10.1155/2015/189402

Kusumastuty, I., Harti, L.B., dan Misrina, S. A. (2016). Perbedaan Kandungan Serat Pangan pada Makanan Siap Saji Khas Indonesia yang Dianalisis dengan Menggunakan Nutrisurvey dan Enzimatik Gravimetri. Majalah Kesehatan FKUB 3 (4): 196-204.

Li, Y. O., dan Komarek, A. R. (2017). Dietary Fibre Basics: Health, Nutrition, Analysis, and Applications. Food Quality and Safety 1: 47-59.

Liguori, I., Russo, G., Curcio, F., Bulli, G., Aran, L., Della-Morte, D., Gargiulo, G., Testa, G., Cacciatore, F., Bonaduce, D., dan Abete, P. (2018). Oxidative Stress, Aging and Diseases. Clinical Interventions in Aging 13: 757-772.

Marsono, Y., Ratu S., dan Noor. Z. (2005). Antioksidan Dalam Kacang-Kacangan: Aktivitas dan Potensi Serta Kemampuannya Menginduksi Pertahanan Antioksidan Pada Model Hewan Percobaan. Hibah Bersaing Penelitian XII/2.

Martinez, C. J., Martinez, A. C., Ayala A.L M., Muzquiz, M., Pedrosa, M. M., dan DavilaOrtiz, G. (2012). Changes in Protein, Nonnutritional Factors, and Antioxidan Capacity during Germination of L. campestris Seeds. International Journal of Agronomy 2012: 1 - 7.

Megat, R. M. R., Azrina, A., dan Norhaizan, M. E. (2016). Effect of Germination on Total Dietary Fibre and Total Sugar in Selected Legumes. International Food Research Journal 23 (1): 257-261.

Pizzino, G., Irrera, N., Cucinotta, M., Pallio, G., Mannino, F., Arcoraci, V., Squadrito, F., Altavilla, D., dan Bitto, A. (2017). Oxidative Stress: Harms and Benefits for Human Health. Oxidative Medicine and Cellular Longevity 2017: 1 - 13.

Rahardjo, L. D., Bahar A., dan Adi, A. C. (2019). Pengaruh Kombinasi Kacang Kedelai (Glycine Max) dan Kacang Tunggak (Vigna Unguiculata (L) Walp.) yang Diperkaya Biji Nangka (Artocarpus Heterophyllus) Terhadap Daya Terima dan Kadar Protein
Snack Bar. Research Study Amerta Nutrition: 71-77.

Rajendra, F. M., Kristiani, L. S. dan Ariviani, S. (2019). Elicitation Under Salinity Stress Increases Flavonoid Content and Antioxidant Activity in Cowpea (Vigna unguiculata) Sprouts. IOP Conference Series: Materials Science and Engineering 633 (1): 1-5.

Ratna, S., Arini, H., Sarah, F., Desra, C., dan Nanang, K. (2008). Sereal Tempe "Tem-Q" Alternatif Sarapan Pagi dan Snack Sehat yang Praktis Kaya Protein Nabati. Program Kreativitas Mahasiswa Institut Pertanian Bogor.

Roland, W. S. U., Pouvreau, L., Curran, J., de Velde, F. V., dan de Kok, P. M. T. (2017). Flavor Aspects of Pulse Ingredients. Cereal Chemical 94 (1): 58-65.

Rusydi, M., Noraliza, M.R.., Azrina, A., dan Zulkhairi, A. (2011). Nutritional Changes in Germinated Legumes and Rice Varieties. International Food Research Journal 18: 705-713.

Setyaningsih, D., Apriyantono, A., dan Sari, M. P. (2010). Analisis Sensori Untuk Industri Pangan dan Agro. IPB Press: Bogor.

Sharma, S., Saxena, D.C., dan Ria, C.S. (2016). Analysing The Effect of Germination on Phenolics, Dietary Fibres, Minerals and $\gamma$ Amino Butyric Acid Contents Of Barnyard Millet (Echinochloa frumentaceae). Food Bioscience 13: 60-68.

Singleton, V. L., Orthofer, R., dan LamuelaRaventos, R. M. (1999). Analysis of Total Phenols and Other Oxidation Substrates and Antioxidants By Means of Folin-Ciocalteu Reagent. Methods in Enzymology 299: 152178.

Sukasih, E dan Setyadjit. (2012). Formulasi Pembuatan Flake Berbasis Talas untuk Makanan Sarapan (Breakfast Meal) Energi Tinggi dengan Metode Oven. Jurnal Pascapanen 9 (2): 70-76.

Swieca, M. (2015). Elicitation with Abiotic Stresses Improves Pro-Health constituents, Antioxidant Potential and Nutritional Quality of Lentil Sprouts. Saudi Journal of Biological Sciences 22: 409- 416.

Swieca, M., Baraniak, B., dan Gawlik-Dziki, U. (2013). In Vitro Digestibility and Starch Content, Predicted Glycemic Index and 
Potential In Vitro Antidiabetic Effect of Lentil Sprouts Obtained by Different Germination Techniques. Food Chemistry 138: 1414-1420.

Tang, D., Yinmao, D., Hankun, R., Li, L., dan Congfen, H. (2014). A Review of Phytochemistry, Metabolite Changes, and Medicinal Uses of The Common Food Mung Bean and Its Sprouts (Vigna radiata). Chemistry Central Journal 8: 4-13.

Tarzi, B., Gharachorloo, M., Baharinia, M., dan Mortazavi, S. (2012). The Effect of Germination on Phenolic Content and Antioxidant of Chickpea. Iranian Journal of Pharmaceutical Research 11 (4): 1137-1142

Teixeira-Guedes, C. I., Oppolzer, D., Barros, A. I., dan Wilson, C. P. (2019). Phenolic Rich Extracts from Cowpea Sprouts Decrease Cell Proliferation and Enhance 5Fluorouracil Effect In Human Colorectal Cancer Cell Lines. Journal of Functional Foods 60: 1-8.

Timm, D.A., dan Slavin, J.L. (2008). Dietary Fiber and the Relationship to Chronic Diseases. American Journal of Lifestyle Medicine 2 (3): 233-240.

Utomo, J. S., dan Antarlina, S. S. (1998). Teknologi Pengolahan dan Produk-Produk Kacang Tunggak. MONOGRAF BALITKABI 3: 120-138.

Uwaegbute, A. C., Iroegbu, C. U., dan Eke, O. (2000). Chemical and Sensory Evaluation of Germinated Cowpeas (Vigna ungucuilata) and Their Products. Food Chemistry 68: 141-146.

Yana, F. M dan Kusnadi, J. (2015). Pembuatan Yogurt Berbasis Kacang Tunggak (Vigna Unguiculata) dengan Metode Freeze Drying (Kajian Jenis dan Konsentrasi Bahan Pengisi). Jurnal Pangan dan Agroindustri 3 (3): 1203-1213. 